\title{
Project Management Practices and Critical Success Factors-A Developing Country Perspective
}

\author{
Daniel F. Ofori ${ }^{1}$ \\ ${ }^{1}$ University of Ghana Business School, University of Ghana, Ghana \\ Correspondence: Daniel F. Ofori, Department of Organisation and Human Resource Management, University of \\ Ghana Business School, P.O. Box LG 78, Legon, Ghana. E-mail: dofori@ug.edu.gh
}

Received: June 4, 2013

Accepted: Setember 6, 2013

Online Published: October 15, 2013

doi:10.5539/ijbm.v8n21p14

URL: http://dx.doi.org/10.5539/ijbm.v8n21p14

\begin{abstract}
The study sought to identify and assess the quality of project management practices as well as the critical success factors for projects in Ghana. The study adopted an exploratory approach and utilized a survey method to collect data on project management practices of Ghanaian organizations. Purposive sampling was used in selecting the sample which comprised 200 managers from different economic sectors. Results from the study indicated that the critical factors that contribute to the success of a project include top management support, effective communication, clarity of project purpose and goals, and stakeholder involvement. Documentation and dissemination of critical success factors and best practices in project management will improve the quality of project management in Ghana.

The absence of a structured system of documentation of project management practices among Ghanaian project managers has resulted in a dearth of empirical data. The inability of the researchers to sample organisations across Ghana is considered as one of the study's limitations, an example of a geographical constraint. This research focused on the key factors and best practices that lead to the success of projects in Ghana.
\end{abstract}

Keywords: project management, critical success factors, quality, Ghana

\section{Introduction}

Project Management has gained popularity as a distinct management concept used to drive not only business objectives, but also the economic development agenda of developing countries including Ghana. Several programmes in Ghana, such as real estate development, event planning, product development, infrastructure development, especially those tied to foreign aid from development partners, and Ghana's own development policy programmes like the Presidential Special Initiatives (PSI) (Ghana Investment Promotion Centre [GIPC], 2001) and the Ghana Poverty Reduction Strategy Papers (GPRS I \& II) (National Development Planning Commission [NDPC], 2002; 2005), all lay heavy emphasis on the use of projects and project management as a tool to optimize the rate of success. Chatfield (2007) defines project management as the discipline of planning, organizing and managing resources to bring about the successful completion of specific project goals and objectives.

According to the Project Management Institute's (PMI, 2008) Body of Knowledge (PMBOK) projects, which are temporary endeavours undertaken to meet unique goals and objectives within a defined scope, budget and time frame, typically go through a life cycle. The project life cycle, which is a logical sequence of activities to accomplish the project's goals, is made up five stages namely; the Project Initiation stage, the Project Planning stage, the Project Execution stage, the Monitoring and Controlling stage, and the Project Closure stage. Attention to detail, along with the involvement of key stakeholders and proper documentation at each stage ensures the success and quality of the project. The sequential phases are generally differentiated by the set of activities that are carried out within the phase, the key actors involved, the expected deliverables, and the control measures put in place (Project Management Institute [PMI], 2004).

For example, setting out the scope and specifications of the project at the Initiation stage enables the project sponsor and manager to be clear on the purpose, expected outcomes, budget, deliverables and time frame of the project. In addition to this, experience shows that getting it right at the Planning stage is critical for project success and the sustainability of the project outcomes. Any ad-hoc planning may lead to the consequences of not 
meeting deadlines and thereby increasing cost, which in turn affects the quality of the project. In many cases, even the scope of the project suffers because time-lapse introduces some exigencies that would demand a change in scope or a deviation from scope. Planning should also involve all project stakeholders to guarantee agreement on scope and specifications, as well as support. The Planning stage ties into the Execution of the project during which there should be constant Monitoring and Controlling of all aspects of the project. This is more so for infrastructure and development projects which are often costly and long-term, and hence, errors tend to be equally costly with long lasting effects, usually with some socio-economic implications. Proper monitoring and control or evaluation of projects during execution enhances the success rate of the project.

In Ghana, the promulgation of the Public Procurement Act, 2003 (Act 663) (Public Procurement Authority, 2010), and the enforcement of the regulations thereof, has vastly improved the execution of projects. The successful Closure of a project is linked to the efficiency of the monitoring and evaluation stage. The quality and success of a project is judged not just by the achievement of project specifications and timeliness of the delivery, but also by the perception of the various stakeholders. Thus, upon the completion of a project, the onus lies on the project manager to ensure that the project meets the specifications of the sponsor within the constraints of scope, time, cost and quality, before handing over to the stakeholders. This is necessary not only for donor sponsored projects since they tend to have a higher standard, but also for government and private sector projects as well.

\subsection{Problem Statement, Purpose and Objectives of the Study}

Ghana, as a developing country, is faced with a myriad of project management challenges both technical and non-technical. First and foremost, there is a dearth of empirical studies on the success or otherwise of project management in Ghana, thus leaving no documentation on the best practices in that field. Secondly, whilst projects in general have their challenges regarding implementation and consequently success, development projects in particular are plagued by a unique set of problems and challenges. For example, the very nature of project funding in Ghana poses a significant challenge for government as well as non-governmental agencies. The funding provided by donors for development projects is so extensive that they are now referred to as development partners, a reflection of how dependent Ghana's development is on donor support (Ofori, 2006). This financial support comes with conditionalities which affect the project right from the pre-planning stage throughout the entire project life cycle. The experience is that, in addition to projects reflecting the donor's thematic area rather than meeting a development need of the expected beneficiaries, donor interests often put a spanner in the wheels resulting in delays in implementation, changes in scope, and occasionally an abrupt cancellation of a project. Furthermore, cultural issues related to deferment, hierarchy, notions of respect, taboos and other aversions often impact project management negatively (Awuah, 2008). These challenges in project management have an impact on the overall quality and success of projects in Ghana.

Due to the myriad challenges facing project managers in Ghana, the purpose of the study was to identify and assess the quality of project management practices by determining and ranking the factors that affect project success. Knowledge of the best practices would improve the quality of project management and consequently project success. This study contributes to the body of knowledge on project management best practices and critical success factors, within a developing country context.

The objectives of the study were;

(i) To identify and assess the quality of Project Management Practices of Ghanaian Organisations;

(ii) To identify the critical success factors of project management in Ghana;

(iii) To ascertain whether key variables such as age and size of the firm affect project success; and

(iv) To provide recommendations for the improvement of project success.

To help meet the objectives, the following over-arching questions guided the study;

1) What are the project management practices adopted by Ghanaian organisations?

2) How do Ghanaian project management practitioners rank the identified critical factors that affect the success of projects?

3) How can the quality of project management practices be improved for project success in Ghanaian organisations? 


\section{Project Management}

This section of the paper looks at project management, quality of projects and project management practices, project management in Ghana, the critical success factors of project management, and the conceptual framework for the study.

\subsection{Projects and Project Management}

A project, as defined by Wysocki, Beck and Crane (2000), is a sequence of unique, complex, and connected activities having one goal or purpose that must be completed by a specific time, within budget, and according to specification. This can be contrasted from a routine set of activities or daily operations which are intended to be continuous process without a planned end. Projects are also characterized by general attributes such as the purpose, life cycle, uniqueness, interdependencies and conflict (Meredith \& Mantel Jr., 2000). Merna and Al-Thani (2008) also defined a project as a unique investment of resources to achieve specific objectives, such as the production of goods or services, in order to make a profit or to provide a service for a community. A project is an irreversible change with a life cycle and defined start and completion dates. A key characteristic of projects is the role played by a key actor aptly named as project manager. While the project manager is central to the process of project management, $\mathrm{s} / \mathrm{he}$ is only as good as the project team $\mathrm{s} / \mathrm{he}$ leads. Thus, it might be an underestimation to propound that the success or otherwise of a project depends solely on the project manager.

To ensure the success of projects, the project manager must have the requisite knowledge of project management, which is defined as the planning, organisation, monitoring and control of all aspects of a project and the motivation of all involved to achieve project objectives safely and within defined time, cost and performance (PMI, 1996). It is also the application of knowledge, skills, tools, and techniques to project activities to meet project requirements (PMI, 2008). In Pinkerton's (2003) view, project management harnesses the competencies of various individuals, grouping them together and enabling them to achieve the objectives of the project and ensure the success of the project. Quality is a key factor in assessing the success of projects and project management practices.

\subsection{Quality of Projects and Project Management Practices}

Quality is considered an important outcome of a project since the performance measures of projects are usually based on time, cost and quality, also known as the iron triangle (Orwig \& Brennan, 2000). Quality has different attributes - both subjective and objective - some of which are difficult or impossible to quantify. Thus, Stevens (1996) recommended a comprehensive approach to the assessment of project quality to include the traditional project success measures such as cost, schedule and safety, as well as measures such as customer satisfaction, leadership, employee involvement, teamwork, training and responsiveness. McConachy (1996) proposed a dual system of measuring project quality using ratings from what he termed "conventional project quality" and "contemporary project quality". While "conventional project quality" deals with the extent to which the customer's requirements are met with respect to the budget, schedule and technical specifications, "contemporary project quality" is subjective in nature and involves a qualitative assessment of customers and project team members as to how the project is meeting their expectations with regard to issues such as: the communication of goals and values; peer review; customer expectations; partnering and quality awards. For engineering or construction projects, Paquin, Couillard and Paquin (1996) suggested an analogous procedure which assesses "earned quality" as a means of managing the build-up of quality in a project during the design and construction phases.

Another important aspect of quality is the stage at which it is assessed in the life cycle of a project. According to Toakley and Marosszeky (2003), project quality is normally evaluated at the completion stage, though assessments may be undertaken during the various stages of the project. Although the most significant quality decisions are made during the planning and design stages, most of the quality management efforts occur during the implementation phase of the project. The onus for ensuring project quality lies primarily on the project manager and the project team who should endeavour to undertake best practices to ensure successful project management.

\subsection{Project Management in Ghana}

As far back as the mid-1960s, the accelerated provision of infrastructure in the aftermath of colonization saw the emergence of the practice of project management in Ghana. Although there is a dearth of knowledge about project management in Ghana, there is some evidence that after initially embracing project management as a tool for the delivery of developmental initiatives, there was a shift towards developing and implementing several interventions using various approaches, particularly those skewed towards vertical programming. However, as 
Ghana's development became driven by donor-funded interventions, the dictates of stakeholders who were actively funding the development and restructuring of all sectors of the Ghanaian economy, propelled the prominence of project management in the 1980s as a better alternative for delivering development interventions (Ofori \& Sakyi, 2006). The public sector and the private not-for-profit sector, who were the active agents in the transformation of the various sectors of the economy, enhanced their capacity to embrace projectization of the development agenda for better and successful management. By their raison d'être, the not-for profit organizations, often referred to as non-governmental organisations (NGOs) usually use a Project Management approach in implementing their interventions. This is because of the restrictive nature of the scope of the projects, the time frame for delivering development interventions, as well as the budget or resources allocated, all of which are determined by donors and funders.

Ghana, like most developing countries, has been able to develop the nation's infrastructure with the support of donor partners and through the use of projects and project management. These development projects range from the refurbishment of basic schools in various districts, the provision of water and sanitation, support for agriculture and agribusiness, the construction of roads and highways, transportation, and the rural electrification project to name a few (NDPC, 2005; Millennium Development Agency [MiDA], 2011). In response to the multi-faceted nature of the current business environment, corporate Ghana is increasingly adopting innovative Project Management approaches for the achievement of business objectives. This ranges from the provision of services such as event planning to the production of goods in the manufacturing, real estate development and the extractive industries.

Until recently, project management was not taught in schools in Ghana. Rather, technocrats who were thrust into managing projects had to learn from their experiences or through working with project management professionals. With the growing shift towards projects, project management is now being taught in universities as well as by several institutions. The proliferation of announcements of "PMP" i.e. Project Management Professional courses in newspapers, suggests that a demand has been created. This augurs well for ensuring that projects are managed by professionals. However, there is a lack of empirical evidence to show that the acquisition of technical knowledge and project management skills by non-professionals who may be in the very senior management positions have been created as a direct result of the proliferation of institutions offering Project Management training. If indeed, project management is linked with the achievement of corporate objectives and development aspirations, then there should be more focus on project planning with stakeholder analysis, monitoring and evaluation and control. It stands to reason, therefore, that a clear understanding of projects, the best practices and critical success factors in the management of projects are developed.

\subsection{Project Management Critical Success Factors}

Defining project success poses another challenge in understanding project management and consequently assessing its performance. It is generally accepted however, that the success or otherwise of a project can be defined through the convergence of, the ability of the process to meet the technical goals of the project whilst not deviating from the three constraints of scope, time and cost; the usefulness of the project as perceived by beneficiaries and sponsors as well as the project team; and the performance of the project (Kerzner, 1992, 2001, 2003). By such a definition, project success or failure can only be effectively measured at the completion of the project. This is concurred with by Baccarini's (1999) definition of project success which measures success or failure by the elements of the project log-frame and thus, the effective utilisation of the project output. Projects generally fail as a result of poor planning, constant changes in the scope and consequently deadline and budget, as well as the lack of monitoring and control. Boyd (2001) introduced five maxims of measuring project satisfaction regardless of project scope, size or duration which are; delivering the product that the customer desires or needs; delivering quality consistent with price; delivering the project within the timeframe stipulated by the customer; delivering the desired degree of feedback that the customer desires; having a system of conflict resolution that is fair to both the customer and the development team.

DeWit (1988) distinguished between project success, which is measured against the overall objectives of the project, and project management success measured against the widespread and traditional measures of performance against cost, time and quality. Pinto and Slevin (1988) came out with a set of best practices for project management which were believed to contribute to project success. These include: Project Mission - the initial clarity of goals and general direction; Top Management Support - the willingness of top management to provide the necessary resources and authority for project success; Project Schedule/ Plans - a detailed specification of individual action steps required for project implementation; Client Consultation communication, consultation, and active listening to all impacted parties; Personnel - recruitment, selection, and training of the necessary personnel for the project team; Technical Tasks - availability of the required 
technology and expertise to accomplish the specific technical action steps; Client Acceptance - the act of "selling" the final product to its ultimate intended users; Monitoring and Feedback - timely provision of comprehensive control information at each phase in the implementation process; Communication - the provision of an appropriate network and necessary data to all key actors in the project implementation; and Trouble Shooting - ability to handle unexpected crises and deviations from plan. Over the years, a number of researchers, such as Cooke-Davies (2001) and Cleland and Gareis (2006) have concurred that these practices do ensure effective and successful project management.

The complexity of Project Management, particularly monitoring and control and conterminous demand on the time of the project team, has led to the development of various tools for ensuring the project is on track, such as the critical path methodologies, Gantt chart, and other computer-based techniques. Unfortunately, a dependence on these tools can only yield success if from the onset the project management team is able to identify the critical success factors at every phase of the project life cycle. By constantly enquiring whether the project meets the needs of the client; whether the project has the support of management; whether there is appropriate knowledge and skill to support the project; and whether the project is solving the right problem, the team is able to identify the key variables that make for success or failure.

Generally, critical success factors are a set of project variables or factors that are strongly correlated to project success, and whose maximisation or minimisation, depending on whether they are favourable or unfavourable, will lead to project success. According to Rockart (1981), critical success factors are the limited number of areas in which satisfactory results will ensure successful competitive performance for the individual, department, or organization. They are the few key areas where things must go right for the business to flourish. If results in these areas are not adequate, the organization's efforts for the period will be less than desired. Frese and Sauter (2003) conclude that generally, Good Planning, Clear Responsibility and Accountability, and Schedule Control as well as Project leadership and Governance, and Communications are key areas of successful projects. This means that, a clear project plan, a plan for risk management, and the commitment and support from stakeholders are the critical success factors for project management. Khang and Moe (2008) expand this further by recommending the sets of critical success factors for the various phases of the project life cycle as indicated in Table 1.

Table 1. Project critical success factors

\begin{tabular}{cc}
\hline Phase & Success Factors \\
\hline Conceptualizing & $\begin{array}{c}\text { Clear understanding of project environment } \\
\text { Effectiveness of consultation with stakeholders } \\
\text { Competency of project team }\end{array}$ \\
Alanning & Alignment with development priorities \\
& Effectiveness of consultation with stakeholders \\
& Competency of project team \\
Implementation & $\begin{array}{c}\text { Compatibility of regulations for project management } \\
\text { Effectiveness of consultation with stakeholders } \\
\text { Consistency of support for stakeholders } \\
\text { Competency of project team }\end{array}$ \\
& Adequacy of project closure activities \\
Closing & Effectiveness of consultation with stakeholders \\
& Competency of project team
\end{tabular}

Source: Khang, D. B., \& Moe, T. L. (2008).

Despite the various definitions of what constitute project success and failure factors, drawing conclusions on reasons for the success or failure is as complex as project management itself. It is worth noting from the definitions of critical success factors given by various authors that the proverbial project management "iron triangle" is not the only benchmark for measuring success or failure of projects. Fortune and White (2006) reviewed 63 publications that focus on critical success factors (CSF) and surmise that there is only limited agreement among authors on the factors that influence project success. They list the three most cited factors as: the importance of a project receiving support from senior management; having clear and realistic objectives; and 
producing an efficient plan. Bakar, Razak, Abdullah and Awang (2009) also summarize literature review from various authors on project success and failure; pointing to the need for project managers to be more dynamic about the factors that are critical to the success of their project.

The myriad of approaches available in literature allow for appropriate indicators that are measured as and when required. For example, given the influence of tradition on every facet of the economy of Ghana, an assessment for determining critical success factors for project management in Ghana would require a contextualization within a socio-cultural, governmental, political, economic, technical and operational framework.

Table 2. Summary of literature reviews on critical success factors (CFS)

\begin{tabular}{|c|c|c|c|c|c|c|c|c|c|}
\hline \multirow[b]{2}{*}{ Critical Success Factors } & \multicolumn{9}{|c|}{ Authors } \\
\hline & $\begin{array}{l}\text { Pinto } \\
\& \\
\text { Slevin } \\
(1987, \\
1989)\end{array}$ & $\begin{array}{l}\text { Kerzner, } \\
(1992, \\
2001, \\
2003)\end{array}$ & $\begin{array}{l}\text { Yeo, } \\
(2002)\end{array}$ & $\begin{array}{l}\text { Boyd } \\
(2001)\end{array}$ & $\begin{array}{l}\text { Andersen } \\
\text { et. al, } \\
(2002)\end{array}$ & $\begin{array}{l}\text { Hyvari } \\
(2006)\end{array}$ & $\begin{array}{l}\text { Turner } \\
\& \\
\text { Muller } \\
(2005, \\
2007)\end{array}$ & $\begin{array}{l}\text { Khang } \\
\& \text { Moe } \\
(2008)\end{array}$ & $\begin{array}{l}\text { Frese } \\
\& \\
\text { Sauter } \\
(2003)\end{array}$ \\
\hline $\begin{array}{l}\text { Clear Project Management } \\
\text { objectives }\end{array}$ & $\sqrt{ }$ & & $\sqrt{ }$ & & $\sqrt{ }$ & & & $\sqrt{ }$ & $\sqrt{ }$ \\
\hline Top Management Support & $\sqrt{ }$ & & $\sqrt{ }$ & & $\sqrt{ }$ & $\sqrt{ }$ & $\sqrt{ }$ & $\sqrt{ }$ & $\sqrt{ }$ \\
\hline Information/Communication & $\sqrt{ }$ & & & $\sqrt{ }$ & $\sqrt{ }$ & $\sqrt{ }$ & & & $\sqrt{ }$ \\
\hline Client Involvement & $\sqrt{ }$ & $\sqrt{ }$ & & $\sqrt{ }$ & $\sqrt{ }$ & $\sqrt{ }$ & & $\sqrt{ }$ & \\
\hline Competent Project Team & $\sqrt{ }$ & & & & & $\sqrt{ }$ & $\sqrt{ }$ & $\sqrt{ }$ & \\
\hline $\begin{array}{l}\text { Authority of the Project } \\
\text { Manager/Leader }\end{array}$ & $\sqrt{ }$ & & & & $\sqrt{ }$ & & & & \\
\hline Realistic Cost and Time Estimates & $\sqrt{ }$ & $\sqrt{ }$ & $\sqrt{ }$ & $\sqrt{ }$ & & & & & \\
\hline Adequate Project Control & $\sqrt{ }$ & & & & $\sqrt{ }$ & & & & $\sqrt{ }$ \\
\hline Problem Solving Abilities & $\sqrt{ }$ & & & & & $\sqrt{ }$ & & & \\
\hline Project Performance and Quality & & $\sqrt{ }$ & & $\sqrt{ }$ & & & & & \\
\hline Adequate Resources & $\sqrt{ }$ & $\sqrt{ }$ & & & $\sqrt{ }$ & $\sqrt{ }$ & & $\sqrt{ }$ & \\
\hline Planning/controlling & $\sqrt{ }$ & $\sqrt{ }$ & $\sqrt{ }$ & & $\sqrt{ }$ & & $\sqrt{ }$ & $\sqrt{ }$ & $\sqrt{ }$ \\
\hline Monitor performance and feedback & & & $\sqrt{ }$ & $\sqrt{ }$ & & $\sqrt{ }$ & $\sqrt{ }$ & & \\
\hline Project mission/common goals & $\sqrt{ }$ & & & & $\sqrt{ }$ & $\sqrt{ }$ & & & \\
\hline Project ownership & $\sqrt{ }$ & $\sqrt{ }$ & & & & & $\sqrt{ }$ & $\sqrt{ }$ & $\sqrt{ }$ \\
\hline
\end{tabular}

Source: Critical Success Factors (CFS) identified across publications.

\subsection{Conceptual Framework}

Considering the various variables that could constitute critical success factors for project management, assessing the quality of project management practices and critical success factors in Ghanaian organizations can be best undertaken using a conceptual model that embraces time, cost, scope as well as social, cultural, economic, political, communication, competency, stakeholder involvement and leadership among others. Guided by this and a conceptual model for assessing sustainable development interventions, a conceptual framework for this study has been generated by the researchers. See Figure 1 . 


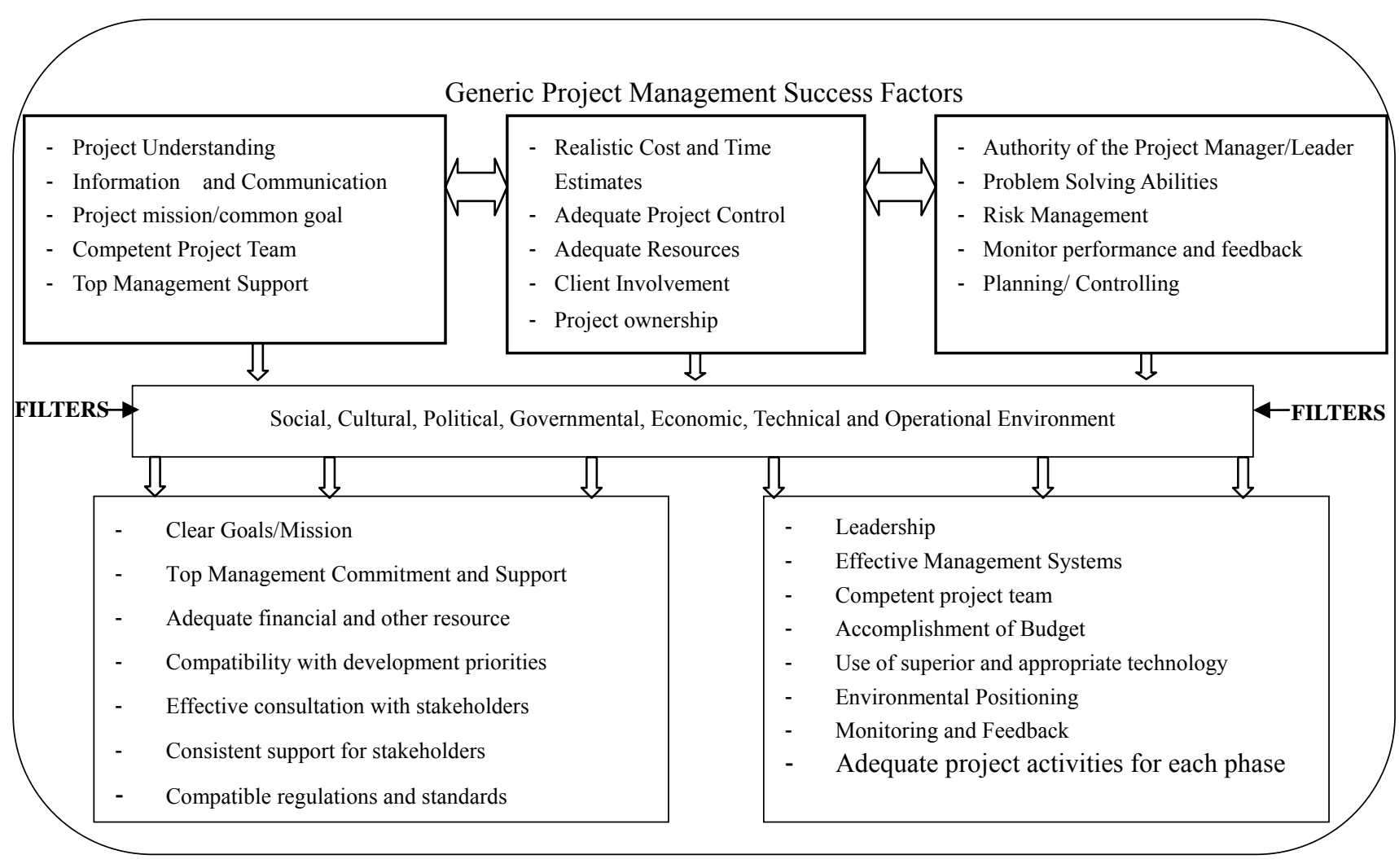

Figure 1. Conceptual framework for assessing the quality of project management practices and critical success factors in Ghanaian organizations

Source: Self-generated by Authors, 2010.

The framework for the study encompasses some of the project management practices believed to result in successful projects as well as factors that are held to contribute directly to project success namely; Clarity of project mission and goals, Top management support, Well-laid out specifications, Competency of project personnel, Effective consultation with project stakeholders, Effective communication, Adequate financial resources, Teamwork, Leadership, and Client/ Beneficiary Satisfaction as seen in the literature review (Pinto \& Slevin, 1988; Stevens, 1996; Cooke-Davies, 2001; Cleland \& Gareis, 2006). The above framework expresses how project management practices and success factors, and their expected outcomes are influenced by factors endogenous to the environment the project is being carried out. These factors can be socio-cultural, political, governmental, and economic as well as technical and operational environments. The socio-cultural factors for example can influence a project design, and implementation may consider peculiar cultural factors germane to particular beneficiaries. In a developing country such as Ghana, changes in government have the tendency to affect project fund allocation, compatibility with development priorities (design changes) as well as management competencies (Leadership changes) etc, which culminate in project delays and often affect project success. The endogenous factors thus act as a filter and the stronger and more pervasive they are, the higher the impact they are likely to have on project outcomes as is set out in Figure1.

\section{Methodology}

The study was exploratory in nature and utilized a survey methodology for data collection. The target population was the 2010 intake of the Executive MBA class of the University of Ghana Business School. The EMBA class comprised managers and decision-makers of a number of organizations ranging from banks, consulting firms, manufacturing industries, construction companies, public sector enterprises to non-governmental organizations (NGOs).

Using the purposive sampling technique, 200 respondents with some knowledge of the project management practices within their organizations, based on their job position or function, were selected. 
Table 3. Respondent company profile

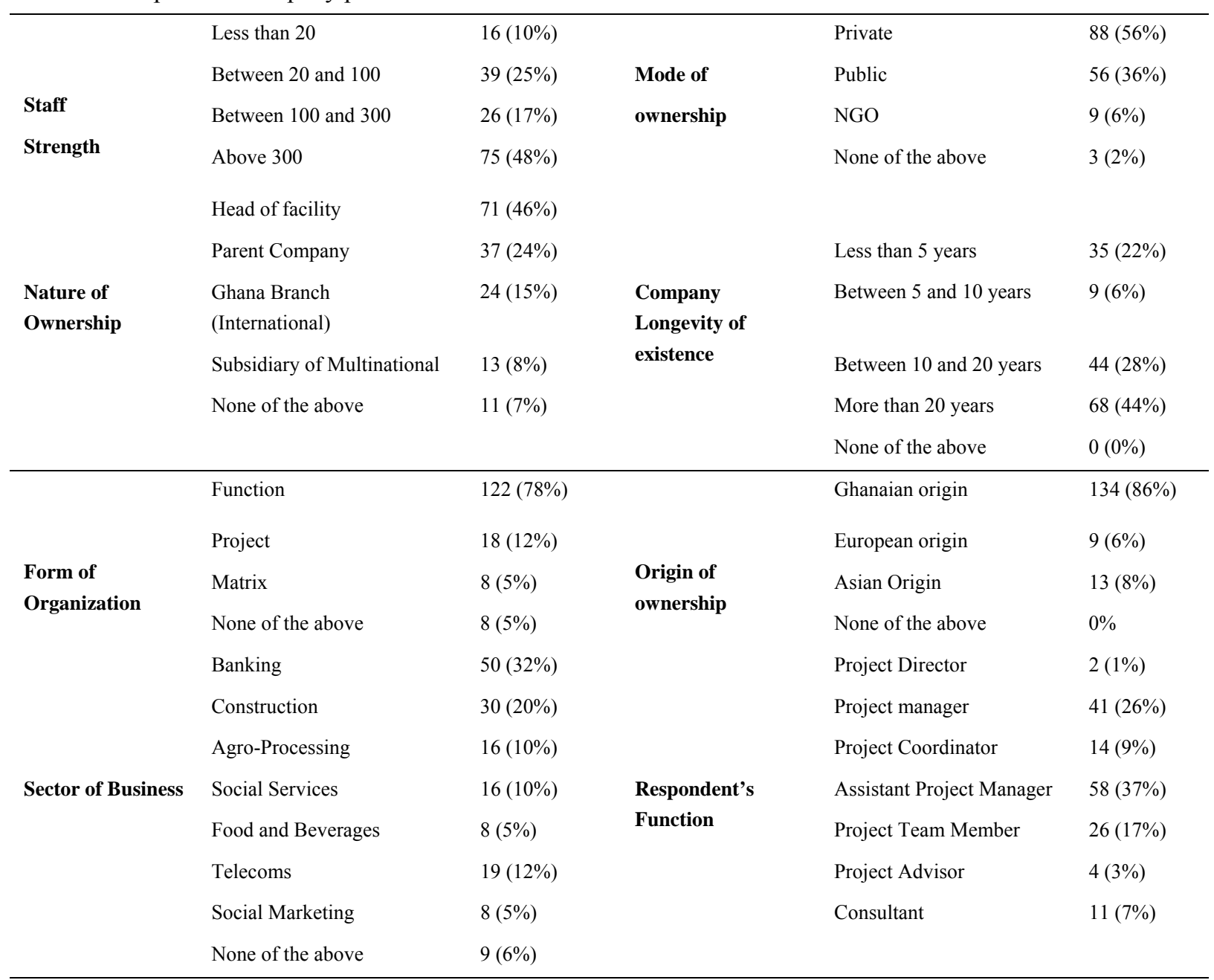

Source: Survey Data, 2010.

\subsection{Summary of Sample Characteristics}

- Company Staff Strength: Forty-eight percent (48\%) of the respondents indicated that the total staff strength of the organizations they work for is above 300, while $17 \%$ had a staff strength above 100 . This means that as much as $65 \%$ of the surveyed organizations are large by Ghana standards.

- Mode of Ownership: The sample showed that $6 \%$ of the organizations studied were NGOs, $56 \%$ from the Private sector, 36\% from the Public Sector organizations, and 2\% not stated.

- Nature and Origin of Ownership: Eighty-six percent (86\%) of the organizations studied were Ghanaian owned, with $14 \%$ being of European or Asian origin.

- Respondents' Function: With regard to the function of respondents, only $37 \%$ were in senior level positions (Consultant, 7\%; Project Advisor, 3\%; Project Director, 1\%; and Project Manager, 26\%). The rest were in Middle management or Supervisory positions, namely Project Coordinator (9\%), Assistant Project Manager (37\%), Project Team Member, (17\%).

- Form of Organization: Of the number of organizations surveyed, $78 \%$ were organized according to function. Although a majority of respondents work in the private sector which is expected to be more dynamic and more inclined to being organized according to projects, the data indicated that only $12 \%$ was thus organized. The data showed that $5 \%$ of companies surveyed were organized in a matrix form, with another $5 \%$ being organized according to market and geographic territory among others. 


\subsection{Survey Questionnaire}

A 27-item questionnaire was developed for collecting data on the project management practices of various organizations in Ghana, based on companies' portfolio of projects. The questionnaire, which was designed on the premise of the three research questions listed in Section 1.1 was structured as follows:

- Section A: Company Profile - This section sought data on the age or longevity of existence of the organizations, establishment numbers, form of organization, nature of ownership, organizational structure, origin of ownership, respondents' function, respondents' longevity of service, sector of business activity, size of the company and staff strength.

- $\quad$ Section B: Project Management Practices - The questions in this section sought data on issues related to clarity of project objectives and goals, client satisfaction, commitment and support of top management, communication, competency of project team, consultations with clients and stakeholders, project planning, project staffing, risk management, monitoring and feedback as well as project management performance rating by reviewing the project management practice in respondent's organization.

- $\quad$ Section C: Critical Success Factors - This section of the questionnaire sought data on wide-ranging issues related to perceptions of respondents as pertaining to factors that militate against project success as well as those factors that facilitate project success.

- Section D: Ranking of indentified critical factors for project success - This section attempted to draw conclusions about the factors that were commonly critical to project success.

\subsection{Data Collection and Analysis}

Two hundred (200) questionnaires were administered out of which 156 were completed. This represented a 78\% response rate. Refer to Table 4. The analysis of data, using the Statistical Package for Social Sciences (SPSS), utilized both quantitative and qualitative methods, with cross-tabulations being carried out to clarify the relationships between the variables considered as critical success factors.

Table 4. Distribution and response rate of administered questionnaires

\begin{tabular}{cccc}
\hline Business Sector & Questionnaires Administered & Completed Questionnaires & Response Rate (\%) \\
\hline Banking & 40 & 38 & 95.00 \\
Construction & 40 & 35 & 87.50 \\
Agro-Processing & 20 & 16 & 80.00 \\
Social Services & 20 & 20 & 100.00 \\
Food and Beverages & 20 & 11 & 55.00 \\
Telecoms & 20 & 12 & 60.00 \\
Social Marketing & 20 & 11 & 55.00 \\
Others & 20 & 13 & 65.00 \\
Total & $\mathbf{2 0 0}$ & $\mathbf{1 5 6}$ & $\mathbf{7 8 . 0 0}$ \\
\hline
\end{tabular}

Source: Survey Data, 2010.

\section{Discussion of Findings}

The findings of the study are discussed below in line with our research objectives.

\subsection{Quality of Project Management Practices in Ghana}

The first objective of the study was to identify and assess the quality of project management practices in Ghanaian organisations. This was achieved by comparing the project management practices commonly used by the selected Ghanaian companies to those practices believed to correlate to effective project management and project success as outlined in the literature.

\section{\{Research Question 1: What are the project management practices adopted by Ghanaian Organisations?\}}

The project management practices adopted by Ghanaian organisations to ensure project quality and success were similar to those utilized by Pinto and Slevin (1987; 1988; 1989), Belassi and Tukel (1996), Cleland and Gareis (2006), etc, as indicated in the literature review and conceptual framework for the study. These were found to be: Clarity of overall project mission and goals; Top management support; Well-laid out specifications; 
Competency of project personnel; Effective consultations with stakeholders; Effective communications; Adequacy of contingency plan; and Client' Beneficiary satisfaction. This generally shows an awareness and knowledge of the project management practices.

\subsubsection{Clarity of Overall Project Mission, Purpose and Goals}

Results from the study indicated that $89(57.1 \%)$ of the respondents agreed that the project team and the major stakeholders were clear about the mission and purpose of the project, $48(31 \%)$ of them strongly agreed, 10 (6.4\%) were not sure, $4(2.6 \%)$ disagreed, while $5(3.2 \%)$ strongly disagreed. These results are in line with studies by Wysocki, Beck and Crane (2000), and Meredith and Mantel Jr. (2000) which emphasized the importance of clarity of project mission, purpose and goals.

\subsubsection{Top Management Support}

In terms of top management support for projects, $86(56 \%)$ of the respondents agreed that top management supported projects, $42(27 \%)$ strongly agreed, $13(8 \%)$ were not sure, $7(4 \%)$ of them disagreed, and $8(5 \%)$ of them strongly disagreed. These results reflect those of Yeo (2002), Khang and Moe (2008), Frese and Sauter (2003) and Anderen et al, (2002), who all emphasize the importance of top management support for projects.

\subsubsection{Well-Laid Out Specifications}

The data analysis showed that $90(58 \%)$ of the respondents agreed that projects had well-laid-out and detailed specifications, 32 (21\%) strongly agreed, $16(10 \%)$ of respondents were not sure, $16(10 \%)$ disagreed, and $2(1 \%)$ strongly disagreed. This is in line with studies by Pinto and Slevin (1987, 1989), Turner and Muller (2005), Muller and Turner (2007), and Khang and Moe (2008).

\subsubsection{Competency of Project Personnel}

Further analysis showed that 79 (51\%) of the respondents agreed to the view that the parent organization had the necessary competent personnel to handle projects. Thirteen percent $(13 \%)$ of the respondents strongly agreed, while $28(18 \%)$ of the respondents were not sure. Eighteen percent $(18 \%)$ of respondents disagreed on the availability of competent personnel. Considering that the project manager and the project team are ultimately responsible for the success and quality of projects (Struckenbruck, 1981; Pinto and Slevin, 1987, 1988), its stands to reason that competent personnel would be recruited and trained regularly.

\subsubsection{Effective Consultations with Project Stakeholders}

The study showed that $95(60.9 \%)$ of the respondents agreed that there was adequate and regular consultation with clients, $32(20.5 \%)$ strongly agreed, $12(7.7 \%)$ were not sure, $16(10.3 \%)$ disagreed and $1(0.6 \%)$ of respondents strongly disagreed. According to Anil and Thomasson, (1991), clear responsibility and accountability and communications are generically key areas of successful project management. Khang and Moe (2008) also believe that effective consultation with stakeholders is necessary for success at each phase of the project life cycle.

\subsubsection{Effective Communication}

The data showed that $84(54 \%)$ of the respondents agreed that there was effective communication among project teams, clients and parent organizations; 21 (13\%) of them strongly agreed, $24(15 \%)$ were not sure, $23(15 \%)$ disagreed, while $4(3 \%)$ of the respondents strongly disagreed. Of the eight literary works on critical success factors for project management that Bakar et al (2009) reviewed, four of the authors namely Pinto and Slevin (1987, 1989), Belassi and Tukel (1996), Andersen et al (2006) and Hyvari (2006) identified communication as one of the critical success factors.

\subsubsection{Adequacy of Contingency Plan (Risk Management)}

Seventy-six (76) i.e. $49 \%$ of the respondents agreed that adequate contingency plans, systems or procedures for projects were in place in their organisations; 6 (4\%) strongly agreed, $41(26 \%)$ were not sure, 27 (17\%) disagreed and $6(4 \%)$ strongly disagreed. Pinto and Slevin (1988) and Cleland and Gareis (2006) indicated that trouble shooting or the ability to handle unexpected crises and deviations from plan ensured successful project management and project quality.

\subsubsection{Client/Beneficiary Satisfaction}

Data from the study showed that $54 \%$ of the respondents agreed that project beneficiaries were satisfied with project output; $16 \%$ strongly agreed; $9 \%$ disagreed, whilst $4 \%$ of them strongly disagreed. Twenty-seven (27) of the respondents representing almost $17 \%$ indicated that they were not sure whether project beneficiaries were satisfied with the project outcome or not. The contribution of clients or beneficiary participation in development 
project effectiveness has been widely recognised ever since criticisms of the top-down approach of development projects emerged (Maguire, 1981; Gran 1983 cited in Finsterbusch and Van Wicklin, 2010). These revolutionary writings generated the recognition of the value of the contribution of beneficiaries and for their active participation to be facilitated throughout the project life cycle. Consequently, the satisfaction of beneficiaries has become one of the critical success factors for project management and it is seen as a good measure for sustainability (Finsterbusch \&Van Wicklin, 2010).

\subsection{Critical Success Factors of Project Management}

The second objective of the study was to identify the critical success factors of project management in Ghana. These factors were grouped into two categories; the factors that militate against project success and the factors that facilitate project success as discussed below. Respondents' selections were based on what they considered to be 'most important' factors and respondents were not allowed multiple selections of factors.

Table 5. Factors that militate against project success

\begin{tabular}{lcc}
\hline \multicolumn{1}{c}{ Factors } & Frequency & Percentage (\%) \\
\hline Lack of support/ Finance & 67 & 42.9 \\
Lack of communication, coordination and commitment & 46 & 29.5 \\
Lack of experienced \& competent personnel & 16 & 10.3 \\
Bureaucracy in government institutions & 15 & 9.6 \\
Lack of consultation with stakeholders & 12 & 7.7 \\
Total & $\mathbf{1 5 6}$ & $\mathbf{1 0 0}$ \\
\hline
\end{tabular}

Source: Survey Data, 2010.

The data in Table 5 indicates that almost $43 \%$ of the respondents perceived the lack of support and finance from both clients and top management as a major factor that militates against the achievement of project success. Other factors that serve as a hindrance to successful projects in Ghana include the lack of communication, coordination and commitment; lack of experiences project personnel; bureaucracy in government; and lack of consultation with project stakeholders.

The factors that facilitate project success were found to be effective communication, coordination and commitment; top management support; effective planning; having experienced and competent project personnel; teamwork; and good leadership as shown in Table 6 Respondents' selections were again based on what they considered to be 'most important' factors and respondents were not allowed multiple selections of factors.

Table 6. Factors that facilitate project success

\begin{tabular}{lcc}
\hline \multicolumn{1}{c}{ Factors } & Frequency & Percentage (\%) \\
\hline Effective communication, coordination and commitment & 54 & 34.6 \\
Top management support & 31 & 19.9 \\
Effective planning & 25 & 16.0 \\
Experienced \& competent personnel & 22 & 14.1 \\
Teamwork & 14 & 9.0 \\
Good leadership & 10 & 6.4 \\
Total & $\mathbf{1 5 6}$ & $\mathbf{1 0 0}$ \\
\hline
\end{tabular}

Source: Survey Data, 2010.

The study also sought to determine how some of the critical success factors identified in the literature review (Stevens, 1986; Bakar et al, 2009) were ranked by the respondents.

\{Research Question 2: How do Ghanaian project management practitioners rank the identified critical success factors of projects?\}

Table 7 presents the ranking of the critical success factors identified from the literature review by respondents. 
Table 7. Ranking of critical success factors for project success

\begin{tabular}{lcc}
\hline \multicolumn{1}{c}{ Variable } & Frequency (\%) & Rank \\
\hline Clear mission \& goals & 75.5 & 1 \\
Adequate resources & 67.1 & 2 \\
Top management support \& commitment & 66.3 & 3 \\
Competency of project personnel & 59.0 & 4 \\
Effective communication & 55.2 & 5 \\
Well-laid out specifications & 54.2 & 6 \\
Leadership & 51.8 & 7 \\
Client acceptance/ satisfaction & 45.9 & 8 \\
Client involvement/ consultation & 45.6 & 9 \\
Teamwork & 43.3 & 10 \\
Monitoring \& feedback & 40.8 & 11 \\
Realistic cost \& time estimates & 39.9 & 12 \\
Appropriate technology & 38.0 & 13 \\
Standards \& regulations & 33.3 & 14 \\
Total (N =156) & &
\end{tabular}

Source: Survey Data, 2010.

Respondents' selections were based on what they considered to be 'most important' factors and respondents were not allowed multiple selections of factors. The data showed that in ranking the Critical Success Factors, the respondents ranked Clear Goals and Mission, Adequate Resources, and Top Management Support as the three most important critical success factors for successful projects and project management, while Realistic Cost and Time Estimates, Appropriate Technology, and Standards and Regulations were ranked as the three least important critical success factors.

\subsection{Effect of Age and Size of Company on Factors Affecting Project Success}

The third objective of the study was to ascertain whether key variables such as age and size of the firm affect project success. Cross tabulations were used to assess the effect of firm size and age on project success.

\subsubsection{Factors that Militate against Project Success}

The data analysis shows that the percentage of companies above the age of 10 years who are of the view that Lack of Support/Finance is a factor that militates against project success is $29 \%$ (46) as compared to $13 \%$ (21) of companies less than 10 years who are of the view that Lack of Support/Finance is a factor that militates against project output.

Also, the percentage of companies above the age of 10 years who are of the view that lack of communication, coordination and commitment is a factor that militates against project output is $20 \%$ (31) as compared to $10 \%$ (15) of companies less than 10 years who are of the view that lack of communication, coordination and commitment is a factor that militates against project output. See Table 8 for the cross tabulation.

Table 8. Cross-tabulation of age of company and the factors that militate against project success

\begin{tabular}{|c|c|c|c|c|c|c|}
\hline \multirow{3}{*}{ Factors that militate against project success } & \multicolumn{4}{|c|}{ Age of Company } & \multirow{2}{*}{\multicolumn{2}{|c|}{ Total }} \\
\hline & \multicolumn{2}{|c|}{ Less than 10 years } & \multicolumn{2}{|c|}{ Above 10 years } & & \\
\hline & Freq. & Percent & Freq. & Percent & Freq. & Percent \\
\hline Stakeholders not consulted & 1 & 1 & 11 & 7 & 12 & 8 \\
\hline Lack of support / Finance & 21 & 13 & 46 & 29 & 67 & 43 \\
\hline Lack of communication, coordination and commitment & 15 & 10 & 31 & 20 & 46 & 29 \\
\hline Bureaucracy in government institutions & 6 & 4 & 9 & 6 & 15 & 10 \\
\hline Lack of experienced staff & 6 & 4 & 10 & 6 & 16 & 10 \\
\hline Total & 49 & 31 & 107 & 69 & 156 & \\
\hline
\end{tabular}

Source: Survey Data, 2010. 
Further analysis shows that in-spite of the differences in the percentages, the result of the Pearson chi-square test implies that there is no significant difference between the factors believed to militate against project success for the companies that are less than 10 years old and those older than 10 years.

$$
\left[\chi^{2}(4, N=156)=3.79, p=0.44\right]
$$

As shown in Table 8, the age of a company has no effect on project success. This however does not detract from the fact that the age of a company can denote credibility.

Table 9. Chi-Square tests

\begin{tabular}{lccc}
\hline & Value & df & Asymp. Sig. (2-sided) \\
\hline Pearson Chi-Square & 3.786 & 4 & 0.436 \\
Likelihood Ratio & 4.517 & 4 & 0.341 \\
Linear-by-Linear Association & 1.744 & 1 & 0.187 \\
N of Valid Cases & 156 & & \\
\hline
\end{tabular}

Source: Survey Data, 2010.

From Table 10, the size of a company in terms of staff numbers may not necessarily translate into good quality project management. Rather, other critical success factors such as financial support, good communications including adequate and timely feedback, as well as coordination and commitment are factors that facilitate successful project outputs.

Table 10. Cross-tabulation of size of company (staff strength) and the factors that militate against project success

\begin{tabular}{cccc}
\hline \multirow{2}{*}{ Factors that militate against project success } & \multicolumn{2}{c}{ Size of Company (Staff) } & \multirow{2}{*}{ Total } \\
\cline { 2 - 3 } & Less than 100 & Above 100 & \\
\hline Stakeholders not consulted & $8(5 \%)$ & $4(3 \%)$ & $12(8 \%)$ \\
Lack of support / Finance & $38(24 \%)$ & $29(19 \%)$ & $67(43 \%)$ \\
Lack of communication, coordination \& commitment & $35(22 \%)$ & $11(7 \%)$ & $46(29 \%)$ \\
Bureaucracy in government institutions & $9(6 \%)$ & $6(4 \%)$ & $15(10 \%)$ \\
Lack of experienced staff & $12(8 \%)$ & $4(3 \%)$ & $16(10 \%)$ \\
Total & $102(65 \%)$ & $54(35 \%)$ & $156(100 \%)$ \\
\hline
\end{tabular}

Source: Survey Data, 2010.

The results of the Pearson chi-square test indicates that there is no significant difference between bigger companies with a staff strength above 100 and smaller companies with less than 100 staff with regard to the factors that militate against project success since the significant value $(0.248)$ is greater than 0.05

$$
\left[\chi^{2}(4, N=156)=5.41, p=0.25\right]
$$

This means that the staff strength of an organization has no effect on factors that militate against project success.

\subsubsection{Factors that Facilitate Project Success}

The results of the cross-tabulation in Table 11showed that the percentage of companies above the age of 10 years who consider effective communication, coordination and commitment as a factor that facilitates project success is $23.7 \%$ (37) as compared to $10.9 \%$ (17) of companies less than 10 years. Also, $14.1 \%$ (22) of companies above the age of 10 years considered top management support as a factor that facilitates project output as compared to $5.8 \%$ (9) of companies less than 10 years. 
Table 11. Cross-tabulation of age of company and the factors that facilitate project success

\begin{tabular}{lccc}
\hline \multicolumn{1}{c}{ Factors that facilitate project success } & \multicolumn{2}{c}{ Age of Company } & Total \\
\hline Effective communication, coordination and commitment & Less than 10 years & Above 10 years & $54(34.6 \%)$ \\
Effective planning & $17(10.9 \%)$ & $37(23.7 \%)$ & $25(16 \%)$ \\
Experienced / Skilled personnel & $8(5.1 \%)$ & $17(10.9 \%)$ & $22(14.1 \%)$ \\
Good leadership & $9(5.8 \%)$ & $13(8.3 \%)$ & $10(6.4 \%)$ \\
Team work & $3(1.9 \%)$ & $7(4.5 \%)$ & $14(9 \%)$ \\
Top management support & $3(1.9 \%)$ & $11(7.1 \%)$ & $31(19.9 \%)$ \\
Total & $9(5.8 \%)$ & $22(14.1 \%)$ & $\mathbf{1 5 6}(\mathbf{1 0 0 \% )}$ \\
\hline
\end{tabular}

Source: Survey Data, 2010.

The results of a Pearson chi-square test indicate that there are no significant differences in the factors that facilitate project success for companies older than 10 year and those younger than 10 years

$$
\left[\chi^{2}(5, N=156)=1.66, p=0.89\right]
$$

This means that the age of an organization has no effect on the factors that facilitate the achievement of project success.

Likewise, a cross-tabulation of size of company (staff strength) and the factors that facilitate project success as, shown in Table 12, showed that the factors believed to facilitate project success differed little for companies with staff strength above 100 and those with less than 100 staff. Effective communication, coordination and commitment were considered the most important factor for good quality of project management and project success in organisations in Ghana.

Table 12. Cross-tabulation of size of company (staff strength) and the factors that facilitate project success

\begin{tabular}{lccc}
\hline \multirow{2}{*}{ Factors that facilitate project success } & \multicolumn{2}{c}{ Staff strength (Size) } & \multicolumn{2}{c}{ Total } \\
\cline { 2 - 3 } & Less than $\mathbf{1 0 0}$ & Above 100 & $54(34.6 \%)$ \\
Effective communication, coordination and commitment & $37(23.7 \%)$ & $17(10.9 \%)$ & $25(16.0 \%)$ \\
Effective planning & $14(9.0 \%)$ & $11(7.1 \%)$ & $22(14.1 \%)$ \\
Experienced / Skilled personnel & $15(9.6 \%)$ & $7(4.5 \%)$ & $10(6.4 \%)$ \\
Good leadership & $7(4.5 \%)$ & $3(1.9 \%)$ & $14(9.0 \%)$ \\
Team work & $9(5.8 \%)$ & $5(3.2 \%)$ & $31(19.9 \%)$ \\
Top management support & $20(12.8 \%)$ & $11(7.1 \%)$ & $\mathbf{1 5 6}(\mathbf{1 0 0} \%)$ \\
\hline
\end{tabular}

Source: Survey Data, 2010.

\subsection{Improving Project Success and Quality}

The fourth objective of the study was to determine ways in which project management could be made more effective to ensure project success in Ghana.

\{Research Question 3: How can the quality of project management practices be improved for project success in Ghanaian organisations?

To improve project quality, project managers and top management need to reduce or eliminate the factors that militate against project success outlined in Table 5, and endeavour to incorporate as much of the critical success factors (set out in Tables 6 and 7) as possible in the management of projects. Respondents' views were further 
solicited on how the quality of project management practices can be improved. Table 13 presents a ranking by respondents of factors generated from a thematic clustering of the factors that militate against project success and project critical success factors. The table shows that communication which was ranked first encapsulated issues like mission and goal clarity, stakeholder consultation and realistic cost and time estimates. Commitment, which was ranked second, was comprised of factors like management support, provision of adequate resources and commitment to standards and regulations and quality. Competency, ranked third, addressed issues like experience of project personnel and use of appropriate technology. Coordination, ranked fourth, addressed issues like leadership, teamwork, client involvement, and monitoring and feedback. Thus, according to the respondents, adhering to these critical success factors would greatly improve the quality and success rates of projects in Ghana. This supports research by Khang and Moe (2008) and Ika, Diallo and Thuillier (2011) which shows a positive relationship between critical success factors and project success.

Table 13. Improving quality of project management practices for project success

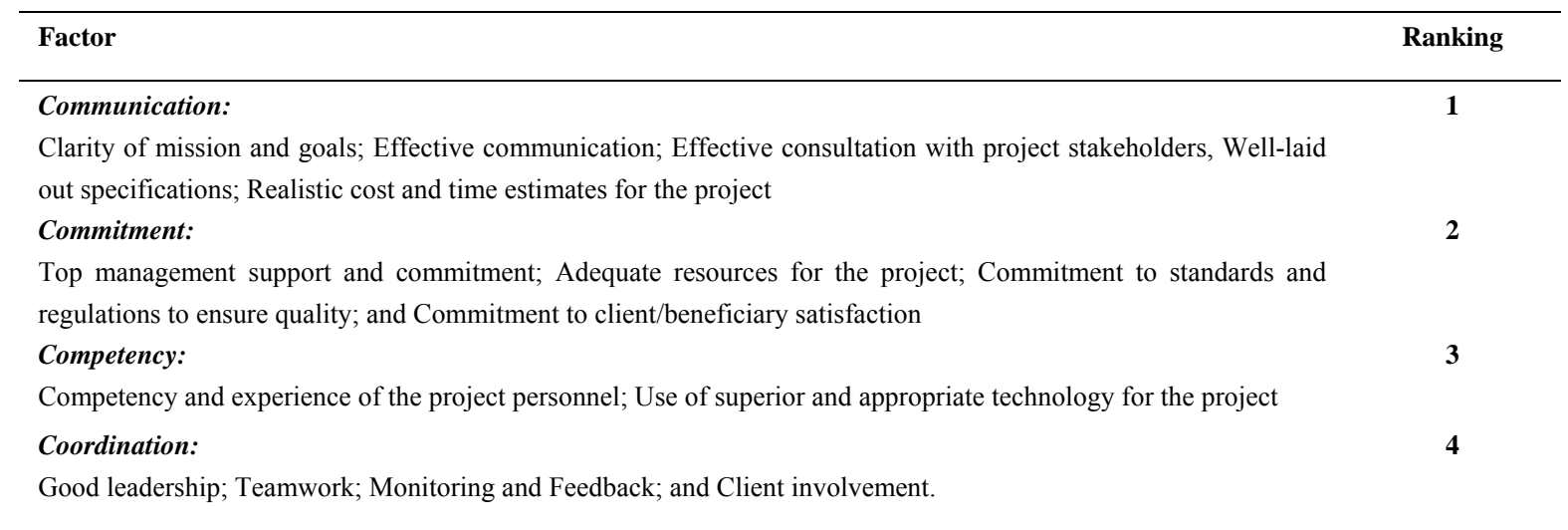

Source: Survey Data, 2010.

\section{Conclusion}

Project management is a valid and legitimate approach to management and has increasingly become an important tool of choice for the realization of objectives across industries and economic sectors. It involves planning, organizing, and managing resources in order to successfully achieve specific project goals and objectives through the completion of specific tasks. The main challenge of project management lies in achieving all of the project goals and objectives while utilizing the resources allocated and adhering to classic project constraints of scope, quality, cost, and time. Organisations in Ghana must also confront these challenges in order to ensure the success of projects undertaken.

The purpose of the study was to assess the quality of project management practices by determining the factors that facilitate project success, such as clarity of project mission and goals, top management support and effective communication, and those that militate against project success, such as lack of support and finance, and lack of effective communication in Ghana. The study also indicated that attention must be paid to the 4Cs communication, commitment, competency, and coordination in order to improve project quality.

\subsection{Limitations of the Study}

In order to provide findings that are reflective of organisations in Ghana, the study should have sampled organisations across the country. However, geographic limitations did not permit this and hence, the sampling of only organisations based in Accra, the capital of Ghana. Secondly, the lack of documentation on project management reduced the data available that could have been incorporated into the study.

\subsection{Recommendations}

Indeed the complexities of project management present some challenges for the success of projects in Ghanaian organisations. This study therefore recommends that at every phase of the project life cycle, the critical success factors should be addressed along with the four Cs, with probably more dynamism than in other situations where there is better project management experience.

\section{References}

Andersen, E. S., Dyrhaug, Q. X., \& Jessen, S. A. (2002). Evaluation of Chinese projects and comparison with 
Norwegian projects. International Journal of Project Management, 20(8), 601-609. http://dx.doi.org/10.1016/S0263-7863(02)00011-X

Andersen, E. S., Birchall, D., Jessen, S. A., \& Money, A. H. (2006). Exploring Project Success. Baltic Journal of Management, 1(2), 127-147. http://dx.doi.org/10.1108/17465260610663854

Anil, I., \& Thomasson, D. (1991). An Empirical Investigation of the Use of Content Analysis to Define the Variables Most Prevalent in Project Successes and Failures. Proceedings of the 1991 PMI Annual Seminar/Symposium, Sept 27-October 2, 1991.

Awuah, M. (2009). Third Encounter: Book 111-Starting a Project. Accra: Project Focus Ltd.

Baccarini, D. (1999). The Logical Framework Method for Defining Project Success. Project Management Journal, 30(4), 25-31.

Bakar, A., Razak, A. A., Abdullah, S., \& Awang, A. (2009). Project Management Success Factors for Sustainable Housing: A $\quad$ Framework. Retrieved from http://eprints.usm.my/16076/1/ICCI09-_14_aidah_awang.pdf

Belassi, W., \& Tukel, O. I. (1996). A New Framework For Determining Critical Success/Failure Factors In Projects. International Journal of Project Management, 14(3), 141-151. http://dx.doi.org/10.1016/0263-7863(95)00064-X

Chatfield, C. (2007). A Short Course in Project Management, Microsoft Office Project 2007 Step by Step. Retrieved from http://www.office.microsoft.com

Cleland, D. I., \& Gareis, R. (2006). Global Project Management Handbook: Planning, Organizing and Controlling International Projects (2nd ed.). USA: The Mc-Graw Hill Companies Inc. Retrieved from http://www.books.google.com

Cooke-Davies, T. J. (2001). Towards Improved Project Management Practices: Uncovering the Evidence for Effective Practices through Empirical Research. Retrieved from http://www.books.google.com

Fortune, J., \& White, D. (2006). Framing of Project Critical Success Factors by a Systems Model. International Journal of Project Management, 24(1), 53-65. http://dx.doi.org/10.1016/j.ijproman.2005.07.004

Frese, R., \& Sauter, V. (2003). Project Success and Failure: What Is Success, What Is Failure, And How Can You Improve Your Odds For Success? Retrieved from http://www.umsl.edu/ sauterv/analysis/6840_f03_papers/frese/

Ghana Investment Promotion Centre. (2001). Presidential Special Initiatives. Retrieved from http://www.gipc.org.gh/otherpages.aspx?id=4

Hyvari, I. (2006). Success of Projects in Different Organizational Conditions. Project Management Journal, $37(4), 31-41$.

Ika, L. A., Diallo, A., \& Thuillier, D. (2011). The Empirical Relationship Between Success Factors and Dimensions: The Perspectives of World Bank Project Supervisors and Managers. International Journal of Managing Projects in Business, 4(4), 711-719. http://dx.doi.org/10.1108/17538371111164092

Kerzner, H. (1992). Project Management: A Systems Approach to Planning, Scheduling and Controlling. New York: Van Nostrand Reinhold.

Kerzner, H. (2001). Project management: A systems approach to planning, scheduling, and controlling (7th ed.). New York: John Wiley and Sons.

Kerzner, H. (2003). Project Management: A Systems Approach to Planning, Scheduling and Controlling. New Jersey: John Wiley \& Sons, Inc.

Khang, D. B., \& Moe, T. L. (2008). Success Criteria and Factors for International Development Projects: A Lifecycle-based framework. Thailand: School of Management, Asian Institute of Technology (AIT).

McConachy, B. R. (1996). Concurrent Management of Total Cost and Total Quality. American Association of Cost Engineers, 2, 1-6.

Meredith, J. R., \& Mantel, S. J. Jr. (2000). Project Management: A Managerial Approach (4th ed.). New York: John Wiley \& Sons.

Merna, T., \& Al-Thani, F. (2008). Corporate Risk Management (2nd ed.). England: John Wiley \& Sons, Ltd.

Millennium Development Authority. (2011). The Millennium Challenge Compact, MiDA, Ghana. Retrieved 
from http://mida.gov.gh/site/?page_id=184

Müller, R., \& Turner, J. R. (2007). Matching the Project Manager's Leadership Style to Project Type. International Journal of Project Management, 25(1), 21-32. http://dx.doi.org/10.1016/j.ijproman.2006.04.003

National Development Planning Commission. (2002). Ghana Poverty Reduction Strategy (GPRS I, 2003-2005). Accra: NDPC.

National Development Planning Commission. (2005). Growth and Poverty Reduction Strategy (GPRS II, 2006-2009). Accra: NDPC.

Ofori, D. F. (2006). Problems of Project Management: Theory, Evidence and Opinion from Ghana. Accra: Ghana Universities Press.

Ofori, D. F., \& Sakyi, K. E. (2006). Problems of Project Management: An Exploratory Ghanaian Study. Proceedings of the Workshop Series on Project Management \& Development. Accra: Woeli Publishing Services.

Orwig, R. A., \& Brennan, L. L. (2000). An Integrated View of Project and Quality Management for Project-Based Organizations. International Journal of Quality \& Reliability Management, 17(4/5), 351-363. http://dx.doi.org/10.1108/02656710010298382

Paquin, J. P., Couillard, J., \& Paquin, R. (1996). Earned Quality: Improving Project Control. Proceedings of the International Conference on Engineering and Technology Management, Vancouver.

Pinto, J. K., \& Slevin, D. P. (1988). Critical Success Factors across the Project Life Cycle. Project Management Journal, 19(3), 67-75.

Pinto, J. K., \& Slevin, D. P. (1987). Critical Success Factors in Effective Project Implementation. In Cleveland D. I. E., \& King, W. R. (Eds.), Project Management Handbook (pp. 719-512). New York: Van Nostrand Reinhold.

Pinto, J. K., \& Slevin, D. P. (1989). Critical Success Factors in R\&D Projects, Research Technology Management, 31-35.

Project Management Institute [PMI]. (2006). A Guide to the Project Management Body of Knowledge. USA: Project Management Institute (PMI).

Project Management Institute [PMI]. (2008). A Guide to the Project Management Body of Knowledge. USA: Project Management Institute (PMI).

Public Procurement Authority. (2010). Public Procurement Act, 2003 (Act 663). Retrieved from http://www.ppaghana.org/documents/std.asp

Rockart, J. F. (1981). A Primer on Critical Success Factors, In Bullen C. V., \& Rockart, J. F. (Eds.), The Rise of Managerial Computing: The Best of the Center for Information Systems Research. Homewood, IL: Dow Jones-Irwin.

Stevens, J. D. (1996). Blueprint for Measuring Project Quality. Journal of Management in Engineering, American Society of Civil Engineers, 12(2), 34-39.

Toakley, A. R., \& Marosszeky, M. (2003). Towards Total Project Quality-A Review of Research Needs. Engineering, Construction and Architectural Management, 10(3), 219-228.

Stuckenbruck, L. C. (1981). The Implementation of Project Management: The Professionals Handbook. Reading, Mass: Addison-Wesley.

Turner, J. R., \& Müller, R. (2005). The Project Manager's Leadership Style as a Success Factor on Projects: A Literature Review. Project Management Journal, 36(2), 49-61.

Wideman, R. (2004). The Role of Project Life Cycle (Life Span) in Project Management. Retrieved from http://www.maxwideman.com/papers/plc-models/plc-models.pdf

Wysocki, R. K., Beck, Jnr. R., \& Crane, D. B. (2000). Effective Project Management (2nd ed.). New York: John Wiley \& Sons, Inc.

Yeo, K. T. (2002). Critical Failure Factors in Information System Projects. International Journal of Project Management, 20(3), 241-6. http://dx.doi.org/10.1016/S0263-7863(01)00075-8 


\section{Copyrights}

Copyright for this article is retained by the author(s), with first publication rights granted to the journal.

This is an open-access article distributed under the terms and conditions of the Creative Commons Attribution license (http://creativecommons.org/licenses/by/3.0/). 